\title{
KARAKTERISTIK KROMIUM ORGANIK HASIL HIDROLIS LIMBAH PADAT PENYAMAKAN KULIT YANG DISINTESIS PADA TEMPERATUR dan KONSENTRASI NaOH BERBEDA SEBAGAI FEED SUPLEMEN SAPI (in vitro)
}

Oleh :

UJANG SURYADI *)

\begin{abstract}
ABSTRAK
Dewasa ini trace mineral selalu ditambahkan ke dalam ransum untuk menyediakan kebutuhan mineral ternak. Trace mineral kromium dalam bentuk organik mulai dieksplorasi penggunaannya untuk kepentingan nutrisi ternak. Kromium organik dapat disintesi dari limbah padat penyamakan kulit melalui proses hidrolisis

Penelitian ini bertujuan untuk mengetahui karakteristik kromium organik yang disintesis pada temperatur dan konsentrasi $\mathrm{NaOH}$ yang berbeda pada kondisi asam di abomasum dan suasana basa di dalam rumen. Karakteristik kromium yang diteliti meliputi kelarutan kromium dan nilai rasio kelarutannya. Nilai kelarutan kromium dapat memberikan informasi tentang ketersediaan kekuatan ikatan kromium dengan agen khelat ketika berada di rumen dan abomasum.

Penelitian dilakukan secara in vitro dengan metode eksperimen. Penelitian menggunakan Rancangan Acak Lengkap dengan 12 kombinasi temperatur dan konsentrasi $\mathrm{NaOH}$ ketika proses hidrolisis yaitu; Temperatur $60{ }^{\circ} \mathrm{C}$, konsentrasi $\mathrm{NaOH} 1 \%\left(\mathrm{~T}_{1} \mathrm{~K}_{1}\right)$, Temperatur $60{ }^{\circ} \mathrm{C}$, konsentrasi $\mathrm{NaOH} 4 \%\left(\mathrm{~T}_{1} \mathrm{~K}_{2}\right)$, Temperatur $60{ }^{\circ} \mathrm{C}$, konsentrasi $\mathrm{NaOH} 7 \%\left(\mathrm{~T}_{1} \mathrm{~K}_{3}\right)$, Temperatur $60{ }^{\circ} \mathrm{C}$, konsentrasi $\mathrm{NaOH} 10 \%\left(\mathrm{~T}_{1} \mathrm{~K}_{4}\right)$, Temperatur $80{ }^{\circ} \mathrm{C}$, konsentrasi $\mathrm{NaOH} 1 \%$ $\left(\mathrm{T}_{2} \mathrm{~K}_{1}\right)$, Temperatur $80{ }^{\circ} \mathrm{C}$, konsentrasi $\mathrm{NaOH} 4 \%\left(\mathrm{~T}_{2} \mathrm{~K}_{2}\right)$, Temperatur $80{ }^{\circ} \mathrm{C}$, konsentrasi $\mathrm{NaOH} 7 \%\left(\mathrm{~T}_{2} \mathrm{~K}_{3}\right)$, Temperatur $100^{\circ} \mathrm{C}$, konsentrasi $\mathrm{NaOH} 1 \%\left(\mathrm{~T}_{3} \mathrm{~K}_{1}\right)$, Temperatur $100{ }^{\circ} \mathrm{C}$, konsentrasi $\mathrm{NaOH} 4 \%\left(\mathrm{~T}_{3} \mathrm{~K}_{2}\right)$, Temperatur $100^{\circ} \mathrm{C}$, konsentrasi $\mathrm{NaOH} 7 \%\left(\mathrm{~T}_{3} \mathrm{~K}_{3}\right)$, dan Temperatur $100^{\circ} \mathrm{C}$, konsentrasi $\mathrm{NaOH} 10 \%\left(\mathrm{~T}_{3} \mathrm{~K}_{4}\right)$.

Simpulan penelitian yaitu kombinasi temperatur dan konsentrasi $\mathrm{NaOH}$ berpengaruh terhadap kelarutan kromium organik hasil hidrolisi di rumen dan abomasum. Nilai rasio kelarutan kromium organik tertinggi 2,10 diperoleh dari proses hidrolisasi pada temperatur $60{ }^{\circ} \mathrm{C}$ dengan konsentrasi $\mathrm{NaOH} 4 \%$, sedangkan nilai rasio kelarutan terendah 0,23 diperoleh dari proses hidrolisasi pada temperatur $80{ }^{\circ} \mathrm{C}$ dengan konsentrasi $\mathrm{NaOH} 10 \%$.
\end{abstract}

Kata kunci : Karaketristik, kromium, limbah, penyamakan kulit 


\section{PENDAHULUAN}

Suplementasi trace mineral dalam ransum bertujuan untuk mendorong ke arah peningkatan produksi ternak seperti pencapaian berat badan, penampilan reproduksi dan sistem imunitas. Tiga unsur trace mineral yang sudah banyak perhatian meliputi tembaga, selenium, dan seng, dewasa ini unsur kromium $(\mathrm{Cr})$ mulai banyak dieksplorasi penggunaannya untuk kepentingan nutrisi ternak.

Kromium merupakan logam berat yang memiliki bilangan valensi +2 sampai +6 . Kromium bervalensi 3 (trivalen), merupakan bentuk yang paling stabil dan mempunyai fungsi fisiologis, namun demikian kromium dengan valensi 3, sangat sukar diabsorpsi dari saluran pencernaan.

Kromium dengan valensi 3, mempunyai bilang koordinasi 6 dan mempunyai kecenderungan besar untuk membentuk komponen koordinasi kompleks dalam berbagai ikatan-ikatan (chelate). Kromium dapat mengikat hormon pada sisi-sisi reseptor atau dapat menstabilkan struktur tersier protein atau asamasam nukleat (Piliang, 1997).

Beberapa penelitian melaporkan bahwa kromium kemungkinan diabsorpsi dengan cara difusi, oleh karena itu transpor kromium dipermudah oleh adanya zat-zat yang membentuk ikatan dengan elemen kromium tersebut. Ion kromium mempunyai afinitas tinggi untuk asam niasin dan kemungkinan hal ini dapat membantu absorpsi kromium (Piliang, 1997).

Kromium adalah mineral mikro esensial yang berperan dalam transportasi glukosa ke dalam sel karena merupakan subtansi anorganik penting dalam hormon insulin. Kromium adalah komponen aktif pada glucose tolerance factors (GTF) dan esensial untuk pemeliharaan metabolisme karbohidrat dan lemak (Mertz, 1993). McNamara dan Valdez (2005) mengatakan bahwa pada ternak yang kekurangan kromium, penambahan kromium dapat meningkatkan penggunaan glukosa oleh insulin untuk pembentuk organ seperti otot dan jaringan adipose.

Sumber kromium dalam pakan jumlahnya relatif sedikit dan bervariasi, sehingga tidak cukup untuk memenuhi kebutuhan kromium tubuh untuk mengaktivasi kerja hormon insulin. Masukan kromium yang berasal dari ransum dan minuman rata-rata 50 sampai 100 mikrogram setiap hari (Pilliang, 2000), oleh karena itu kromium merupakan salah satu komponen mineral mikro yang perlu disuplementasikan pada ransum untuk meningkatan pemanfaatan energi ransum.

Penelitian pada ternak telah menetapkan bahwa unsur kromium dalam bentuk kompleks organik seperti unsur kromium pikolinat ( $\mathrm{CrPic})$, unsur kromium nikotinat ( $\mathrm{CrNic}$ ), dan highchromium yeast, diserap lebih efisien dibanding unsur kromium klorid $\left(\mathrm{CrCl}_{3}\right)$ (Beitz et al., 1997)

Sumber kromium untuk disuplementasikan dalam ransum dapat diperoleh dengan memanfaatkan limbah padat penyamakan kulit krom melalui proses hidrolisis dengan menggunakan $\mathrm{NaOH}$, proses tersebut untuk menurunkan kandungan kromium dan membentuk ikatan kompleks kromium dengan protein kulit sehingga terbentuk kromium organik. Kromium organik dari limbah padat penyamakan kulit sebagai mineral proteinat dapat diperoleh dari hasil khelat garam dapat larut dengan asam amino pada proses hidrolisis protein kulit.

Kromium organik sebagai mineral khelat hasil hidrolisis limbah padat penyamakan kulit harus memenuhi standardisasi produk mineral khelat. Metode standardisasi mineral khelat menjadi pertimbangan utama penerimaan produk mineral organik. Menurut Leach dan Patton (1997), evaluasi mineral khelat dapat dilakukan dengan menganalisis unsur (kandungan mineral dan $\mathrm{N}$ ), kelarutan (efektivitas khelat dan stabilitas pada $\mathrm{pH}$ penyangga berbeda $(\mathrm{pH} 2$ dan $\mathrm{pH} 5)$, evaluasi integritas struktural khelat), dan uji bioavailabilitas mineral (Kerley dan Ledoux, 1992).

Nilai kelarutan $\mathrm{Cr}$ di rumen sampai pascarumen pada ternak rminansia merupakan suatu nilai karakter yang harus diketahui karena dapat digunakan sebagai indikator untuk menilai manfaat dari suatu produk mineral organik dalam menunjang aktivitas bioproses di dalam rumen dan mekanisme metabolisme dalam tubuh ternak, sehingga nilai rasio kelarutan tersebut dapat juga digunakan untuk menentukan kualitas produk mineral organik

Nilai rasio kelarutan suatu mineral organik yang disuplementasikan pada ransum ternak hendaknya dapat memberikan dampak positif bagi kehidupan mikroba rumen yaitu memacu pertumbuhan dan perkembangannya dan berperan serta membantu mikroba dalam proses fermentasi ransum di dalam pencernaan, serta mudah diserap dan bermanfaat untuk proses metabolisme di dalam sel tubuh ternak. Oleh karena itu, untuk menilai manfaat kromium organik yang disintesis dari bahan dasar hidrolisat 
Ujang Suryadi, Karakteristik Kromium Organik Hasil Hidrolis Limbah Padat Penyamakan Kulit Yang Disintesis Pada Temperatur dan Konsentrasi NaOH Berbeda Sebagai Feed Suplemen Sapi

limbah penyamakan kulit krom, maka perlu indikator berupa nilai kelarutan.

\section{METODE PENELITIAN}

Kelarutan kromium organik dievaluasi in vitro yaitu dengan melarutkan tepung kromium organik ke dalam cairan yang memiliki kondisi keasaman relatif sama dengan suasana di rumen ( $\mathrm{pH}$ netral) dan suasana di abomasum ( $\mathrm{pH}$ asam). Evaluasi kelarutan kromium organik dalam cairan netral dilakukan dengan melarutkan 1 gram kromium organik dalam $50 \mathrm{~mL}$ pelarut yang merupakan campuran antara cairan rumen dan larutan McDougall pada perbandingan $1: 4$ pada pH 6,5-6,8, kemudian diinkubasi selama 24 jam pada temperatur $39^{\circ} \mathrm{C}$.

Evaluasi kelarutan kromium organik dalam cairan asam dilakukan dengan melarutkan satu gram kromium organik dalam $50 \mathrm{~mL}$ pelarut $\mathrm{HCl}$
$0,1 \%$ dengan tingkat keasaman pada $\mathrm{pH}$ 2-3 dan diinkubasi selama 24 jam pada temperatur $39{ }^{\circ} \mathrm{C}$. Setelah diinkubasi, supernatan dari setiap larutan kromium organik diambil untuk diukur kandungan kromiumnya dengan menggunakan Atomic Absorbation Spektrofotometer. Nilai rasio kelarutan hidrolisat limbah padat penyamakan kulit ditentukan dengan cara membagi nilai kelarutan kromium di rumen oleh nilai kelarutan kromium di abomasum.

Evaluasi karakteristik kromium organik dilakukan dengan menggunakan Rancangan Acak Lengkap dengan 12 kombinasi temperatur dan konsentrasi $\mathrm{NaOH}$ ketika proses hidrolisis yaitu; Temperatur $60^{\circ} \mathrm{C}$, konsentrasi $\mathrm{NaOH} 1 \%\left(\mathrm{~T}_{1} \mathrm{~K}_{1}\right)$, Temperatur $60^{\circ} \mathrm{C}$, konsentrasi $\mathrm{NaOH} 4 \%\left(\mathrm{~T}_{1} \mathrm{~K}_{2}\right)$, Temperatur $60^{\circ} \mathrm{C}$, konsentrasi $\mathrm{NaOH} 7 \%\left(\mathrm{~T}_{1} \mathrm{~K}_{3}\right)$, Temperatur $60 \quad{ }^{\circ} \mathrm{C}$, konsentrasi $\mathrm{NaOH} \quad 10 \%$ $\left(\mathrm{T}_{1} \mathrm{~K}_{4}\right)$, Temperatur $80^{\circ} \mathrm{C}$, konsentrasi $\mathrm{NaOH} 1 \%$ $\left(\mathrm{T}_{2} \mathrm{~K}_{1}\right)$, Temperatur $80^{\circ} \mathrm{C}$, konsentrasi $\mathrm{NaOH} 4 \%$ $\left(\mathrm{T}_{2} \mathrm{~K}_{2}\right)$, Temperatur $80^{\circ} \mathrm{C}$, konsentrasi $\mathrm{NaOH} 7 \%$ $\left(\mathrm{T}_{2} \mathrm{~K}_{3}\right)$, Temperatur $100{ }^{\circ} \mathrm{C}$, konsentrasi $\mathrm{NaOH}$ $1 \%\left(\mathrm{~T}_{3} \mathrm{~K}_{1}\right)$, Temperatur $100{ }^{\circ} \mathrm{C}$, konsentrasi $\mathrm{NaOH} \quad 4 \% \quad\left(\mathrm{~T}_{3} \mathrm{~K}_{2}\right)$, Temperatur $100 \quad{ }^{\circ} \mathrm{C}$, konsentrasi $\mathrm{NaOH} 7 \%\left(\mathrm{~T}_{3} \mathrm{~K}_{3}\right)$, dan Temperatur $100{ }^{\circ} \mathrm{C}$, konsentrasi $\mathrm{NaOH} 10 \%\left(\mathrm{~T}_{3} \mathrm{~K}_{4}\right)$.

\section{HASIL DAN PEMBAHASAN}

Hasil evaluasi terhadap kelarutan kromium organik disajikan pada Tabel 1

Tabel 1. Kelarutan Kromium Organik Hasil Hidrolisis pada Temperatur dan Konsentrasi NaOH Berbeda di Dalam Rumen dan Abomasum

\begin{tabular}{|c|c|c|c|c|c|c|c|c|c|c|c|c|}
\hline \multirow{2}{*}{$\begin{array}{c}\text { Kelarutan } \\
\mathrm{Cr}\end{array}$} & \multicolumn{12}{|c|}{ Perlakuan } \\
\hline & $\mathrm{T}_{1} \mathrm{~K}_{1}$ & $\mathrm{~T}_{2} \mathrm{~K}_{1}$ & $\mathrm{~T}_{3} \mathrm{~K}_{1}$ & $\mathrm{~T}_{1} \mathrm{~K}_{2}$ & $\mathrm{~T}_{2} \mathrm{~K}_{2}$ & $\mathrm{~T}_{3} \mathrm{~K}_{2}$ & $\mathrm{~T}_{1} \mathrm{~K}_{3}$ & $\mathrm{~T}_{2} \mathrm{~K}_{3}$ & $\mathrm{~T}_{3} \mathrm{~K}_{3}$ & $\begin{array}{l}\mathrm{T}_{1} \mathrm{~K} \\
4\end{array}$ & $\mathrm{~T}_{2} \mathrm{~K}_{4}$ & $\mathrm{~T}_{3} \mathrm{~K}_{4}$ \\
\hline $\begin{array}{c}\text { Rumen } \\
(\%)\end{array}$ & $\begin{array}{c}04,41 \\
\mathrm{c}\end{array}$ & $\begin{array}{c}11,51 \\
\mathrm{abc}\end{array}$ & $\begin{array}{c}34,98 \\
\mathrm{a}\end{array}$ & $\begin{array}{c}18,30 \\
a b c\end{array}$ & $\begin{array}{c}32,07 \\
\mathrm{ab}\end{array}$ & $\begin{array}{c}24,55 \\
\mathrm{~b}\end{array}$ & $\begin{array}{c}03,61 \\
\mathrm{c}\end{array}$ & $\begin{array}{c}12,28 \\
\text { abc }\end{array}$ & $\begin{array}{c}17,84 \\
\text { abc }\end{array}$ & $\begin{array}{c}04,34 \\
\mathrm{c}\end{array}$ & $\begin{array}{c}10,23 \\
\text { abc }\end{array}$ & $\begin{array}{c}07,18 \\
\text { bc }\end{array}$ \\
\hline $\begin{array}{c}\text { Abomasu } \\
\text { m } \\
(\%)\end{array}$ & $\begin{array}{c}7,46 \\
\mathrm{e}\end{array}$ & $\begin{array}{c}20,27 \\
\text { de }\end{array}$ & $\begin{array}{c}48,24 \\
\text { b }\end{array}$ & $\begin{array}{c}8,65 \\
\text { e }\end{array}$ & $\begin{array}{c}71,74 \\
\mathrm{a}\end{array}$ & $\begin{array}{c}25,56 \\
\text { de }\end{array}$ & $\begin{array}{c}7,82 \\
\mathrm{e}\end{array}$ & $\begin{array}{c}27,34 \\
\text { cd }\end{array}$ & $\begin{array}{c}17,73 \\
\text { de }\end{array}$ & $\begin{array}{c}8,73 \\
\mathrm{e}\end{array}$ & $\begin{array}{c}44,52 \\
\text { bc }\end{array}$ & $\begin{array}{c}22,27 \\
\text { de }\end{array}$ \\
\hline $\begin{array}{c}\text { Rasio } \\
\text { kelarutan }\end{array}$ & $\begin{array}{c}0,59 \\
b\end{array}$ & $\begin{array}{c}0,57 \\
\mathrm{~b}\end{array}$ & $\begin{array}{c}0,73 \\
b\end{array}$ & $\begin{array}{c}2,10 \\
\mathrm{a}\end{array}$ & $\begin{array}{c}0,45 \\
\mathrm{~b}\end{array}$ & $\begin{array}{c}0,96 \\
\mathrm{ab}\end{array}$ & $\begin{array}{c}0,46 \\
b\end{array}$ & $\begin{array}{c}0,45 \\
\mathrm{~b}\end{array}$ & $\begin{array}{c}1,01 \\
\mathrm{ab}\end{array}$ & $\begin{array}{c}0,50 \\
b\end{array}$ & $\begin{array}{c}0,23 \\
\mathrm{~b}\end{array}$ & $\begin{array}{c}0,32 \\
b\end{array}$ \\
\hline
\end{tabular}

Keterangan : Huruf yang sama ke arah baris menunjukkan tidak berbeda nyata.

1

\section{- Kelarutan Cr Produk Kromium Organik di}

\section{Rumen}

Berdasarkan Tabel 4.2, Cr yang larut di dalam rumen (larutan netral, $\mathrm{pH}$ cairan rumen 6,8) memiliki variasi yang tinggi antar perlakuan. Kelarutan $\mathrm{Cr}$ dari kromium organik yang dibuat pada temperatur hidrolisis $60^{\circ} \mathrm{C}$ dengan konsentrasi $\mathrm{NaOH} 7 \% \quad\left(\mathrm{~T}_{1} \mathrm{~K}_{3}\right)$ memiliki nilai paling rendah yaitu hanya $03,61 \%$. Nilai kelarutan tersebut memberikan gambaran bahwa 
$\mathrm{Cr}$ yang terikat asam amino pada kromium organik relatif kuat, sehingga tidak terdegradasi di dalam rumen.

$\mathrm{Cr}$ yang larut dari kromium organik yang dibuat pada temperatur hidrolisis $100{ }^{\circ} \mathrm{C}$ dengan konsentrasi $\mathrm{NaOH} \quad 1 \%\left(\mathrm{~T}_{3} \mathrm{~K}_{1}\right)$ memiliki nilai kelarutan yang tinggi yaitu $34,98 \%$, hal ini menunjukkan khelat antara $\mathrm{Cr}$ dengan asam amino hasil hidrolisis protein kulit sangat lemah sehingga menyebabkan $\mathrm{Cr}$ mudah terionisasi di dalam rumen.

Hasil analisis pengaruh kombinasi temperatur hidrolisis dan konsentrasi $\mathrm{NaOH}$ pada sintesis kromium organik terhadap kelarutan kromium di dalam rumen memberikan pengaruh nyata $(\mathrm{P}<0,05)$. Hasil uji jarak berganda Duncan menunjukkan bahwa kromium organik yang disintesis dengan kombinasi perlakuan temperatur hidrolisis $60{ }^{\circ} \mathrm{C}$ dengan konsentrasi $\mathrm{NaOH} 1 \%$, $7 \%$ dan $10 \%$ nyata $(\mathrm{P}<0.05)$ memiliki kelarutan kromium lebih rendah dibandingkan dengan kelarutan kromium yang disintesis dengan kombinasi perlakuan temperatur hidrolisis $80{ }^{\circ} \mathrm{C}$ dan $100{ }^{\circ} \mathrm{C}$ dengan konsentrasi $\mathrm{NaOH} 1 \%, 4 \%$, $7 \%$ dan $10 \%$. Hal ini memberi gambaran bahwa temperatur hidrolisis lebih berperan dalam mempengaruhi stabilitas khelat asam amino terhadap $\mathrm{Cr}$.

Nilai kelarutan $\mathrm{Cr}$ di dalam rumen penting diketahui untuk memastikan konsentrasi $\mathrm{Cr}$ di dalam rumen serta dampaknya terhadap mikroba rumen, sehingga dapat ditentukan batas konsentrasi maksimum kebutuhan kromium organik yang dapat ditolerir.

Konsentrasi maksimum kebutuhan mineral yang dapat ditolerir adalah konsentrasi ketika ternak diberi ransum untuk suatu periode waktu terbatas, mineral yang terkandung di dalam ransum tidak menggangu proses pencernaan dan tidak berbahaya bagi ternak yang menkonsumsinya (NRC, 1996).

Kromium organik yang memiliki nilai kelarutan rendah di dalam rumen memungkinkan lolos dari degradasi dan akan teralirkan bersama digesta menuju saluran pencernaan berikutnya untuk dapat diserap di usus

\section{Kelarutan Cr Produk Kromium Organik di Abomasum}

Nilai kelarutan $\mathrm{Cr}$ di dalam abomasum (larutan asam, $\mathrm{pH} 2-3$ ), kromium organik hasil hidrolisis pada temperatur $80^{\circ} \mathrm{C}$ dengan $\mathrm{NaOH}$ $4 \%\left(\mathrm{~T}_{2} \mathrm{~K}_{2}\right)$ memiliki nilai kelarutan paling tinggi yaitu $71,74 \%$. Nilai kelarutan $\mathrm{Cr}$ tersebut menunjukkan bahwa efektivitas khelat asam amino terhadap unsur $\mathrm{Cr}$ pada kromium organik sangat lemah pada suasana asam di dalam abomasum.
Efektivitas khelat asam amino terhadap unsur $\mathrm{Cr}$ dengan ikatan yang kuat dihasilkan oleh kromium organik hasil hidrolisis pada temperatur $60{ }^{\circ} \mathrm{C}$ dengan $\mathrm{NaOH} 1 \% \quad\left(\mathrm{~T}_{1} \mathrm{~K}_{1}\right)$ yang memiliki nilai kelarutan $\mathrm{Cr}$ terendah yaitu 7,46\%. Kromium organik tersebut menunjukkan bahwa efektivitas khelat asam amino terhadap unsur kromium sangat kuat (stabil) pada suasana asam di dalam abomasum, sehingga memungkinkan dapat digunakan sebagai mineral organik untuk disuplementasikan ke dalam pakan sapi. Miles dan Henry (1999) menyampaikan bahwa manfaat utama dari mineral organik yang dirasakan yaitu mineral organik sebagai khelat memiliki stabilitas yang kuat pada $\mathrm{pH}$ rendah.

Hasil analisis kombinasi temperatur dan konsentrasi $\mathrm{NaOH}$ terhadap kelarutan kromium di dalam abomasum memberikan pengaruh nyata $(\mathrm{P}$ $<$ 0,05). Hasil uji jarak berganda Duncan menunjukkan bahwa kromium organik yang disintesis pada temperatur hidrolisis $60{ }^{\circ} \mathrm{C}$ dengan konsentrasi $\mathrm{NaOH} 1 \%$, diikuti kombinasi perlakuan temperatur hidrolisis $60{ }^{\circ} \mathrm{C}$ dengan konsentrasi $\mathrm{NaOH} 4 \%, 7 \%$, dan $10 \%$ nyata $(\mathrm{P}<$ 0,05) memiliki nilai kelarutan $\mathrm{Cr}$ di abomasum paling rendah dibandingkan dengan kelarutan kromium yang disintesis dengan kombinasi perlakuan temperatur hidrolisis $80{ }^{\circ} \mathrm{C}$ konsentrasi $\mathrm{NaOH} 4 \%, 7 \%$ dan temperatur hidrolisis $100{ }^{\circ} \mathrm{C}$ dengan konsentrasi $\mathrm{NaOH} 1 \%$. Hal ini menunjukkan bahwa kromium organik yang disintesis pada temperatur hidrolisis $60{ }^{\circ} \mathrm{C}$ memiliki kekuatan khelat asam amino dan $\mathrm{Cr}$ yang kuat dibandingkan dengan kromium organik yang disintesis dengan temperatur hidrolisis 80 ${ }^{\circ} \mathrm{C}$ dan $100{ }^{\circ} \mathrm{C}$ pada suasana asam di abomasum.

Rendahnya nilai kelarutan mineral di dalam abomasum menjadi tujuan pembuatan mineral organik untuk disuplementasikan pada pakan yang sedang mengalami stres. Marcy (2005) yang mengemukakan bahwa pemberian mineral inorganik tidak efektif untuk membantu pemenuhan kebutuhan mineral pada saat ternak mengalami stres, tetapi mineral harus diberikan dalam bentuk mineral khelat.

Pemberian mineral dalam bentuk khelat penting dilakukan ketika ternak dalam keadaan stress, karena sistem metabolis pada sel usus tidak berfungsi dengan baik sehingga sulit membentuk mineral mudah diserap, pada akhirnya ketersedian mineral yang mudah diserap kurang di dalam usus. Beberapa penelitian menunjukkan bahwa penyedaian mineral khelat dalam ransum diabsorpsi lebih banyak dan mempunyai kegunaan lebih baik (U.S. patent application No. 60/884,890, 2007).

Ashmead et al. (1989), bahwa pada saat kondisi stres cenderung untuk menimbulkan 
Ujang Suryadi, Karakteristik Kromium Organik Hasil Hidrolis Limbah Padat Penyamakan Kulit Yang Disintesis Pada Temperatur dan Konsentrasi NaOH Berbeda Sebagai Feed Suplemen Sapi

masalah sekunder yang memperburuk gejala stres yang utama diantaranya infeksi usus yang dapat mengakibatkan malabsorpsi sehingga dapat merintangi pengambilan trace mineral esensial dan atau co-factor metabolik. Pada umumnya malabsorpsi terjadi pada duodenum yang merupakan bagian dari usus halus tempat terjadinya penyerapan ion logam dalam kondisi normal. Penyerapan mineral di duodenum memerlukan suatu molekul pembawa mineral berupa protein atau turunannya sebagai tempat menempel dan membawanya ke dalam selaput mukosa untuk mempermudah penyerapan.

Lebih lanjut Ashmead et al. (1989) menjelaskan timbulnya gangguan malabsorpsi mineral pada usus dapat menyebabkan terjadinya reaksi khelat yang tidak diinginkan (seperti bereaksi dengan mineral lain) di dalam sistem pencernaan sehingga penyerapan mineral lebih dipersulit, maka suplementasi mineral dalam ransum sebaiknya disediakan dalam bentuk khelat asam amino atau peptida untuk meningkatkan penyerapan mineral.

\section{Nilai Rasio Kelarutan Kromium di Rumen : Abomasum}

Nilai rasio kelarutan $\mathrm{Cr}$ tertinggi dimiliki oleh kromium organik hasil hidrolisis pada temperatur hidrolisis $60^{\circ} \mathrm{C}$ dengan konsentrasi $\mathrm{NaOH} \quad 4 \% \quad\left(\mathrm{~T}_{1} \mathrm{~K}_{2}\right)$, yaitu 2,10 . Nilai rasio kelarutan $\mathrm{Cr}$ terendah dimiliki oleh kromium organik hasil hidrolisis pada temperatur $80{ }^{\circ} \mathrm{C}$ dengan konsentrasi $\mathrm{NaOH} 10 \% \quad\left(\mathrm{~T}_{2} \mathrm{~K}_{4}\right)$, yaitu 0,23. Perbedaan antar kombinasi perlakuan setelah uji jarak berganda Duncan menunjukkan bahwa kromium organik yang disintesis dengan kombinasi perlakuan temperatur hidrolisis $60{ }^{\circ} \mathrm{C}$ dengan konsentrasi $\mathrm{NaOH} 4 \%\left(\mathrm{~T}_{1} \mathrm{~K}_{2}\right)$, yaitu 2,10 nyata $(\mathrm{P}<0,05)$ memiliki nilai rasio kelarutan $\mathrm{Cr}$ paling tinggi dibandingkan dengan nilai rasio kelarutan $\mathrm{Cr}$ yang disintesis pada temperatur hidrolisis $80{ }^{\circ} \mathrm{C}$ dengan konsentrasi $\mathrm{NaOH} 10 \%$ $\left(\mathrm{T}_{2} \mathrm{~K}_{4}\right)$, yairu 0,23 .

Bila ditinjau dari nilai rasio kelarutan $\mathrm{Cr}$, stabilitas ikatan antara khelat asama amino dengan kromium pada produk kromium organik hasil sintesis limbah penyamakan kulit dipengaruhi oleh kondisi $\mathrm{pH}$ di dalam saluran pencernaan.

Nilai rasio kelarutan $\mathrm{Cr}$ yang tinggi pada kombinasi perlakuan temperatur hidrolisis $60{ }^{\circ} \mathrm{C}$ dengan konsentrasi $\mathrm{NaOH} 4 \%$ terjadi karena lingkungan $\mathrm{pH}$ di rumen menyebabkan pelepasan $\mathrm{Cr}$ dari agen khelatnya lebih tinggi dibanding pada kondisi asam di abomasum, dengan demikian kromium organik yang disintesis dari kombinasi perlakuan tersebut memiliki stabilitas khelat yang lemah pada suasana $\mathrm{pH}$ mendekati netral di rumen.

Kromium organik yang disintesis pada temperatur hidrolisis $60{ }^{\circ} \mathrm{C}$ konsentrasi $\mathrm{NaOH} 4 \%$ memiliki stabilitas khelat yang kuat terhadap degradasi asam di abomasum. Hal ini sangat diharapkan dalam mengefektifkan penyerapan kromium di abomasum. Abomasum merupakan bagian perut ternak ruminansia yang berhubungan dekat dengan duodenum yang diketahui sebagai tempat penyerapan unsur nutrisi diantaranya mineral.

Kelarutan kromium organik yang rendah berpengaruh positif terhadap pemenuhan kebutuhan kromium. Rendahnya kelarutan tersebut menunjukan kelarutan kromium proteinat tetap stabil artinya kromium tetap terikat oleh asam amino. Kondisi kuatnya agen khelat mengikat kromium, hal ini sangat diharapkan untuk mempermudah penyerapan kromium di saluran pencernaan tanpa perlu ada lagi proses pengikatan oleh protein yang dihasilkan mucosa sel duodenum yang memerlukan aktivasi sistem enzimatis.

\section{KESIMPULAN}

Kromium organik yang disintetis dari limbah padat menyamakan kulit memiliki kelarutan di rumen dan di abomasum yang berbeda pada setiap kombinasi temperatur dan konsentrasi NaOH. Nilai rasio kelarutan kromium organik tertinggi 2,10 diperoleh dari hidrolisasi pada temperatur $60{ }^{\circ} \mathrm{C}$ dengan konsentrasi $\mathrm{NaOH} 4 \%$, sedangkan terendah 0,23 diperoleh dari hidrolisasi pada temperatur $80{ }^{\circ} \mathrm{C}$ dengan konsentrasi $\mathrm{NaOH} 10 \%$.

\section{DAFTAR PUSTAKA}

Ashmead, H., Harvey, Dewayne, Graff, and J. Darrell. 1989. Amino Acid Chelated Compositions for Delivery to Specific Biological Tissue Sites. US Patent 4863898.

Beitz, D., G. Fahey, D. Gatlin., R.L. Horst, A.J. Lewis, C. Parsons, A. Pell, G.D. Potter, and M. Witttenberg. 1997. The Role of Chromiumin Animal Nutrition. Committee on Animal Nutrition Board on Agriculture National Research Council National Academy Press. Washington. 
Kerley, M. S., and D. R. Ledoux. 1992. Practical Applications for Chelated Minerals in Cattle. In: Proc. Natl. Feed Ingredient Assoc. Nutr. Inst., Natl. Feed Ingredients Assoc., Des Moines, IA. Pp 1-12.

Leach, G. A., and R. S. Patton. 1997. Analysis Techniquea for Chelated Minerals Evaluated. Feedstuffs. 69 (13) : 13-15.

Marcy W. 2005. Beef Cattle Mineral Nutrition. Dept. of Animal and Range Sciences-1287.

Miles, R.D., and P.R. Henry. 1999. Relative Trace Mineral Bioavailability. Proc. Calif. Animal Nutrition Conference. Fresno, CA.
McNamara J. P. and F. Valdez. 2005. Adipose Tissue Metabolism and Production Responses to Calcium Propionate and Chromium Propionate. J. Dairy Sci. 88 : 2498-2507.

Mertz, W. 1993. Chromium in Human Nutrition: A review. J. Nutr. 123:626-633.

NRC. 1996. Nutrient Requirements of Beef Cattle. 7th ed. National Academy Press, Washington, DC.

Piliang, W.G. 1997. Nutrisi Mineral. Edisi Kedua. Institut Pertanian Bogor. Bogor.

U.S. Provisional Patent Application No. 60/884,890. 2007. Branched Chain Amino Acid Chelate. Ser. No. 12/014,065. 